\title{
THE ROLE OF IMPLICIT THEORIES IN THE NON-EXPERT TRANSLATION PROCESS ${ }^{1}$
}

\author{
Marisa Presas Corbella \\ Universitat Autònoma de Barcelona (Spain) \\ Marisa.Presas@uab.cat \\ Celia Martín de León \\ Universidad de Las Palmas de Gran Canaria (Spain) \\ celia.martin@ulpgc.es
}

\begin{abstract}
Research into the role of implicit theories in decision-making covers a broad area ranging from personal to political relationships, and from private to professional life. To date, translation studies have paid little attention to the influence of translators' knowledge and beliefs in the translation process, and even less to the role of implicit theories. In a pilot study with translation trainees, we attempted to reconstruct their theories about translation and discern to what extent these theories influence both the translation process and the translated text. Our results so far show that trainees do entertain initial implicit theories, which can be modified through experience and formal instruction. These initial implicit theories mainly focus on the notions of transfer and change, and do not reflect the complexity of translation phenomena. With regard to the translation process, our analysis of corrections as well as the length and structure of text-production segments suggests that the informants approach translation at a micro level, which may be partly due to the influence of their concept of translation as transfer. This pilot study is part of a broader research project that analyzes the evolution of initial implicit theories about translation as a result of experience and formal training, and to what extent changes in the theoretical framework of translation trainees can bring about changes in the way they translate.
\end{abstract}

1. Our research on implicit theories is part of PETRA's on-going project Caracterización objetiva de la dificultad general de los originales (Proyecto CODIGO, FFI2010-15724), funded by the Spanish Ministry for Science and Innovation. 


\section{Resumen}

La investigación del papel de las teorías implícitas en la toma de decisiones cubre áreas tan dispares como las relaciones personales y la política, la vida profesional y la privada. Hasta el momento, la traductología apenas ha prestado atención a la influencia de los conocimientos y las creencias del traductor en el proceso de traducción y mucho menos al papel de las teorías implícitas. En un estudio piloto con estudiantes de traducción, hemos tratado de reconstruir sus teorías sobre la traducción y de averiguar hasta qué punto influyen en el proceso y en el texto final. Los resultados, hasta el momento, muestran que, en efecto, los estudiantes poseen teorías implícitas iniciales y que estas teorías pueden cambiar por efecto de la instrucción formal y de la experiencia. El mayor número de estas teorías iniciales se centra en los conceptos de traslado y cambio, y no reflejan la complejidad del fenómeno de traducir. En lo que concierne al proceso de traducción, el análisis de las correcciones, y también de la longitud y la estructura de los segmentos de producción textual, sugiere que los informantes lo abordan en el nivel micro, lo que en parte se puede atribuir a su concepto de la traducción como traslado. Este estudio piloto forma parte de un proyecto más amplio que investiga la evolución de las teorías implícitas iniciales como resultado de la experiencia y de la instrucción, y en qué medida los cambios en el marco teórico inicial de los estudiantes producen a su vez cambios en sus procesos de traducción.

Keywords: Implicit theories. Translation process research. Conceptual metaphor. Translation patterns. Translator training.

Palabras clave: Teorías implícitas. Investigación sobre el proceso de traducción. Metáfora conceptual. Patrones de traducción. Formación de traductores.

Manuscript received on April 29, 2013 and accepted on September 25, 2013. 


\section{Introduction}

In the 1970s, research into problem-solving processes showed that people may make decisions without necessarily taking into account rational factors and, more to the point, that people do not seem to be aware of what they know or the basis of their decisions (Reber 1993: 13). Within this view, two basic forms of human learning have been proposed: (a) explicit learning, in which subjects actively respond to training-for instance, by formulating rules and hypotheses to support their knowledge construction processes; and (b) implicit learning, in which strategic processes play a minor role, if at all. Studies on implicit learning (review in Reber 1993) revealed that it plays a role even in the acquisition of complex knowledge and that it is not a sporadic or marginal phenomenon in human cognition (Reber 1993: 15).

Implicitly- or unconsciously-acquired knowledge has been studied under different labels, such as everyday understanding, implicit theories, folk theories, subjective theories and beliefs. Here we will use the term implicit theory, so as to highlight that they are in principle unconscious. Several disciplines have studied implicit theories, such as social psychology, cognitive psychology, evolutionary psychology, sociology, philosophy of language, and pedagogy. Each discipline has addressed different questions, which can broadly be summarized as follows (Rodrigo et al. 1993: 13):

- How are implicit theories represented?

- How is their content organized?

- How are they used to meet environmental demands?

- Why are they unconscious?

- What role do they play in the cognitive system?

- How are they built and modified as a result of experience or instruction?

In the history of translation studies, metaphors like TRANSFER, TARGET Or IMITATION are ubiquitous, and several works have shown that these metaphors are not just ways of speaking about translation, but also cognitive constructs that support domain conceptualizations for both social groups and theoretical 
approaches (D’hulst 1992; Chesterman 1997; Martín de León 2008; Tymozcko 2010a). In our research, we assume that metaphors can structure and reflect not only the individual knowledge of an expert translator (Martín de León 2010), but also implicit theories from laypeople. Our preliminary results show that translation trainees do entertain initial implicit theories about translation, that these theories can be structured and verbalized through metaphors, and that both practical experience and the study of scientific theories can modify these initial folk-theoretical views. Martín de León \& Presas (2011) analyzed these theories; Martín de León \& Presas (forthcoming) studied their evolution and stability, and Presas \& Martín de León (2011) discussed the suitability of a qualitative approach for our research goals. Here we present the results of a study on translation processes and discuss the relationships between these processes and our informants' implicit theories.

\section{Implicit theories, scientific theories, and conceptual change}

Implicit theories may be described as networks of mental representations derived from experience (Mandl 1998). They are basically unconscious, complex systems of conceptual knowledge (Reber 1993: 5) with an if/then structure (Groeben 1988) that can be modified through experience (Dann 1990) as well as through verbal instruction (Pozo 2003). Two assumptions are especially relevant for our study: together with other factors, implicit theories may influence observable behavior, particularly in the case of goal-oriented actions; and they can be made conscious under some specific conditions; for instance, when they can be related to experience or when they have been recently activated during intentional behavior (Dann 1990: 228). The way implicit theories are constructed has been approached both as an individual and as a social matter. As an individual phenomenon, the emphasis lies on the experience of individuals and their processes of induction or abstraction; as a social phenomenon, the role of collective experience and how it is transmitted in everyday situations is the focus of attention. Ross (1997) pointed out that, unlike scientific theories, implicit theories are inductive, specific and inconsistent, and that they blend covariance with cause-effect relationships. However, some common traits can be found in inductive and scientific theories (Dann 1990, Rodrigo et al. 1993): they are sets of interrelated concepts, both are applied when interpreting reality and explaining it through causal relations, and they include operational routines that guide people's actions and let them predict future events.

The concept of implicit theory is also rooted in theories of conceptual change. Vygotsky (1962) distinguished between spontaneous and scientific 
concepts and pointed out that, as a result of formal education, spontaneous concepts undergo changes and restructuring. In the last 20 years, research into conceptual change has tried to identify the mechanisms of these changes and their implications for curriculum design. Most research has focused on children and teenagers, but many conclusions can be applied to adults as well (Pozo 2003). Studies into conceptual change assume that students' initial knowledge is organized as a relatively coherent structure of domain-specific knowledge, i.e., a framework theory that includes an ontology and causal relationships. Conceptual change consists of students progressively replacing beliefs and assumptions in their initial subjective theories that come into conflict with the new information they learn.

Conceptual changes are difficult because framework theories of this nature are somewhat consistent explanatory systems based on practice, and because they are constantly confirmed through everyday experience. What is more important, people are not conscious that other people may have different beliefs, nor do they know that their own beliefs may not be true facts of the material world, but hypotheses that can be tested and falsified. In fact, students are often able to evaluate the adequacy of their framework theories against reality and, if necessary, to start a deliberate process of conceptual change, but they rarely put their hypotheses to the test (Vosniadou 2008). Research into the acquisition processes of scientific theories shows that students mostly use bottom-up, implicit, and additive mechanisms in order to modify their initial theories. These mechanisms work unconsciously and over an extended period of time, and they often give rise to so-called synthetic models (Vosniadou et al. 2008) that unveil students' attempts to merge two incompatible pieces of information or concepts: one from their previous knowledge, the other one acquired during the formal instruction process.

\section{Conceptual knowledge in translation process research}

Translation process research assumes that knowledge determines both translation processes and products (Muñoz 2008, 2010). Process data is interpreted as "(observable) indicators of (unobservable, mental) translation strategies" (Lörscher 2005: 599). Research has focused on procedural knowledge and has sought to define problem-solving models as well as to discover and classify translators' strategies, both in experts and in novices. Indicators of the role of conceptual knowledge in these processes are also obtained tangentially and are (explicit) data that may be interpreted as expressions of (implicit) translation theories. The use of think-aloud techniques in particular has fostered spontaneous expression by informants of their theoretical conceptions 
when reflecting on their problems and solutions. However, little attention has been paid to the contents and nature of this knowledge in expert translators, while in the case of novices it has often been deemed idiosyncratic, erroneous, or incoherent (Krings 1986, Hönig 1997). Within the framework of their research on translators' competence, PACTE (2008, this volume) studied the variable "knowledge of translation". This variable was defined as "the subject's implicit knowledge of the principles of translation and aspects of the translation profession" (2008: 111). Their priority was not to reconstruct the implicit theories of their experimental subjects, but rather to characterize them with respect to two indicators: "dynamic index" and "coherence coefficient". Accordingly, data was collected with a closed questionnaire, and the subjects' opinions were elicited by means of two-alternative forced choices. Ordóñez (2010) also used a closed questionnaire to trace first-year students' preconceptions about translation. Likewise, her aim was not to reconstruct her students' implicit theories but to detect their educational needs in order to adapt materials and methodologies for a translation course. Finally, Rodrigues (2001) focused on translators' beliefs and tried to reconstruct their knowledge and to study its influence on the translation process. Our study draws partly on Rodrigues' research as well as on Hönig's and Krings' observations.

\subsection{Maxims and rules in the translation process}

Krings (1986: 429) ambiguously defined maxims as "evaluation strategies independent from the problem' and described them as "instructions." Such instructions were taken to be mostly idiosyncratic or arbitrary general principles that his informants applied when evaluating a particular solution. In his view, maxims could be used to relate translation problems to general rules, thus making it easier for the individual to find a solution, but the arbitrary and idiosyncratic nature of these maxims could render results inadequate. Krings (1986: 434) concluded that only in very few cases did these maxims contribute to solving problems. It should be pointed out that Krings evaluated (and rejected) his informants' maxims by contrasting them with the functionalistic translation theory. This does not mean, however, that his informants did not have a theory. Krings himself suggested (1986: 469) that maxims derive from a knowledge system that the students had built up during the acquisition of a second language, in which translation is used as a task to practice and to evaluate the students' use of grammar structures. In fact, several informants

2. Unless otherwise stated, all translations are ours. 
provided the same maxims, albeit differently expressed, so it can be hypothesized that they are in part influenced by social factors.

Hönig (1997) discussed rules in a specific theoretical context, namely the debate questioning the usefulness of translation theory, and stated that even translators who reject theory "work unconsciously with a repertoire of rules or norms without reflecting on them" (Hönig 1997: 25). These rules become explicit when discussing translation quality and are idiosyncratic and persistent. Hönig described his informants' rules as instructions, generalizations, and commonplaces expressed during their evaluation of concrete solutions. These rules constitute each translator's "creed" or "dogma" (1997: 25) and they show individual traits, although at the same time they seem widely shared. In Hönig's view, rules are placed in a "controlled workspace" and do influence the translation process. For instance, sometimes his informants (translation trainees) rejected adequate solutions by arguing "absurd" reasons. Hönig did not discuss the way these rules are acquired, but referred to Vermeer (1992), who attributed them to the influence of society, media, and learning institutions.

In our view, Krings' and Hönig's conclusions about the characteristics and function of maxims and rules hint at the difficulty of capturing unconscious knowledge. Their work suggests that (a) it is not very structured and consists of instructions and theoretical statements; (b) the relationships between the components of unconscious knowledge are often inconsistent; (c) knowledge systems seem to develop individually, although they are influenced by external factors, especially from social institutions; and (d) individuals seem to attribute truth-value to this knowledge.

\subsection{Beliefs and the translation process}

Some of the traits of unconscious knowledge as described by Krings and Hönig, and summarized above, were the main assumptions in Rodrigues (2001), who focused on the role of beliefs in the translation process. He defined beliefs as "principles, assumptions and ideas about the translation process and its result, which have been formed through translators' direct experience. They are knowledge structures associated with a subjective feeling of truth" (2001:7). His research tested two hypotheses: (a) there is a relationship between translators' beliefs and their decisions; and (b) there is a relationship between translators' experience and their beliefs. In his study, informants' beliefs were reconstructed and contrasted with their decisions during problem-solving processes. Rodrigues' results yielded two major findings (2001: 557ff): (1) beliefs work as variables in decision-making processes, 
although their influence is weaker than that of other variables, such as text type and language command; (2) despite differences between informants' experiences, their beliefs show a high level of agreement.

\subsection{A model of implicit theories in the translation process}

The construct of implicit theories of translation is based on the assumption that translators not only apply operational knowledge to understand and translate texts, but also conceptual or theoretical knowledge to guide these processes. Our tentative model of implicit theories largely builds upon the findings by Krings, Hönig, and Rodrigues outlined above. In brief, implicit theories:

- refer to several phenomena, such as the translation's aim, the translator's role, the equivalence relations between source and target language, and the use of dictionaries;

- are structured in a variety of ways, such as concepts, instructions, rules, metaphors and beliefs; while some of these mental representations are mutually consistent, others are mutually incompatible or exclusive;

- are built through induction and generalization from particular cases but they lack systematic and deliberate reflection, so they are not very flexible and can lead to overgeneralizations;

- are applied to problem evaluation and problem solving, so they do influence the translation process;

- only partially agree with commonly accepted theories of translation.

Although we assume that implicit theories about translation are built mainly through individual processes, social and cultural influences cannot be ruled out. In fact, the notion of socially-shaped translation theories has been conceptualized as translation norms (Toury 1995) or translation memes (Chesterman 1977). Norms or memes reflect shared values that both expert and non-expert translators apply during the translation process (Martín de León \& Presas 2011: 274-276). However, both norms and memes are implicitly seen as reflecting "universal" concepts of translation. Tymoczko (2003, 2010b) has criticized this view and points out that theoretical concepts about translation vary from culture to culture, and change over time (2010b: 58). The notion of the translation process as a "mysterious inner process" itself derives from Western individualism and prevailing Western translation practice; it does not reflect the full range of translation practices worldwide and may not even 
be the prevailing mode cross-culturally (2003: 7-8). Since translation is a complex social concept, research should focus on its "inflections across time, space and cultures" (2010b: 58).

\section{Methodological considerations}

Reviews of research into the translation process (Rodrigues 2001, 2002; Orozco 2002; Jäaskeläinen 2002; Krings 2005) underscore the heterogeneity of research endeavors as to their aims, the number and characteristics of informants, the languages considered and data-collection tools. So, results are hardly comparable. Critical approaches to research methods have focused mainly on two aspects: (1) broadly speaking, on the criteria and methods to ensure quality in research design; and (2), in particular, on the suitability of data-collection methods to reach the intended research goals. The first discussion echoes the debate in humanities and the social sciences about quality in qualitative research. Neunzig (2002) highlighted the shortcomings of qualitative research approaches (case studies) and of some data-collection methods (TAPs, direct observation) as opposed to experimental research and hypothetical-deductive methods. Nevertheless, and somewhat paradoxically, Neunzig also rejected a positivist paradigm for Translation Studies (2002: 91) and supported qualitative quality criteria such as intersubjective transparency in experimental research (2002: 94). Hansen (2004) also focused on objectivity, reliability and validity, and discussed the possibilities of quantifying data, in particular in the case of triangulating evidence from informants' behavior.

In the research design of our pilot study, we chose a comparative approach to contrast implicit theories about translation in a group of translation trainees, with the aim of finding both minimal contrasts (similarities between individuals) as well as maximal contrasts-i.e., variation between them (Flick 2007: 41). When collecting the data, we adopted three triangulation perspectives (Presas \& Martín de León 2011): temporal (data was collected in consecutive time points); methodological—data of different phenomena (thinking and acting) were gathered with different instruments-; and theoretical: data was interpreted within different approaches (metaphor theory and translation process research). The following section sets out our research design and the basis of our methodological choices.

\subsection{Research project and goals of the pilot study}

The main aim of our research project is to develop an "empirical anchorage" (Wahl 1994) for our model of implicit theories about translation. For this, 
we need to (a) determine correlations between mental representations and observable behavior; (b) predict future observable behavior based on reconstructed representations; and (c) modify implicit theories through reflection and check potential variations in observable behavior (Wahl 1994: 259). The aims of our pilot study within this project were:

1. To reconstruct implicit theories in trainee translators by analyzing the metaphors they used.

2. To identify correlations between reconstructed implicit theories and observable behavior during the translation process.

3. To identify correlations between reconstructed implicit theories and the translated text.

4. To explore pedagogical methods to foster cognitive conflict and conceptual change and to test if such conflicts and changes led to changes in the translation process.

5. To explore a specific methodology to reach these goals.

The analysis of metaphorical expressions allows us not only to inductively reconstruct our informant's implicit theories but also to deductively formulate assumptions about their approach to the translation process (micro-strategy or macro-strategy) and also about their priorities when taking textual decisions (formal imitation of source text or orientation to the addressee). In the present stage of our study, we focus on two kinds of data: the students' metaphorical expressions and the students' process data as recorded with Translog. In the next stage we will analyze the students' texts. Our study is partly inspired by action research, both in the methodology applied, which combines diagnosis with action, and in the aim of improving the teaching-learning process.

\subsection{Informants and data collection procedures}

The informants of our pilot study were 10 students in a course on "Theory and Practice of Translation (German)" at the ULPGC School of Translation and Interpreting during the first semester of the academic year 2008-2009. Data regarding their views was collected through three questionnaires, one interview, four theoretical essays, and two commentaries by each student on their translations. In addition, the informants' behavior was recorded with Translog when they were translating five texts. At the beginning of the semester (September 2008), the informants filled out a sociolinguistic questionnaire (Appendix I) and a second one with translation-related questions (Appendix II). A few weeks later (October 2008), informants filled out a third 
questionnaire (Appendix III), where they had to outline their notion of the translation process and describe what happens when a text is translated by means of an image or metaphor. The interviews were carried out in November and December 2008. Their aim was to prompt a metalinguistic reflection from the students about the metaphors they had used. These interviews were audiotaped and transcribed. The theoretical essays were evenly spaced throughout the semester. Three of them dealt with different approaches to translation (Nida, the Leipzig School, functionalism); in the fourth one, they had to answer questions about these different theoretical approaches and outline their own translation theories. The two commentaries on the translations were also spaced throughout the semester. Here, the informants had to explain their decisions during the translation of two advertisements from German into Spanish. Finally, in each of the five translation tasks recorded with Translog (texts 0 to 4), the informants had to translate a children's tale of 400-500 words in an hour. Except for the interviews, which were conducted individually, all tasks were performed simultaneously, so as to ensure equal conditions.

\subsection{Metaphor analysis}

In our research project, we adopted conceptual metaphor theory (Lakoff $\&$ Johnson 1980, Lakoff 1993) as a general framework, although we extended this to accommodate theoretical and methodological research findings on metaphor in real discourse in the last decade (Cameron 2003, Musolff 2004, Cameron \& Deignan 2006, Kövecses 2009, Musolff \& Zinken 2009). Cognitive linguists describe conceptual metaphors as mental operations that allow us to understand the world by creating systematic mappings of inferential structures between two domains, one of which is better known or more accessible to the senses than the other. For cognitive linguistics, these mappings guide experience and action; they can work as cultural models shared by a social group; and they can be reflected in language (Kövecses 1986, Lakoff \& Kövecses 1987, Kövecses 2005). This view of metaphor as a cognitive operation guiding experience is essential in our research, since it sustains one of the initial assumptions of our model, namely that ideas about communication, language and translation, implicit in the metaphors used by translation trainees, have a bearing on the way they translate. For our study, it is also important to determine to what extent implicit theories (as reflected in informants' metaphors) are sociocultural in origin and to what extent they are the result of individual elaboration fostered by training tasks. 
In the last decade, studies on metaphor in real discourse have highlighted the dynamic interplay between the cognitive, linguistic, sociocultural and affective dimensions of metaphor, and they have focused on the social embeddedness of metaphor production and comprehension (Cameron 2003, Cameron \& Stelma 2004, Musolff 2004, Cameron \& Deignam 2006, Cameron 2007, Kövecses 2009, Musolff \& Zinken 2009). We have adopted the main insights of these approaches by considering the communicative situations where metaphors are used, and also by adopting a dynamic perspective. Our study has not focused on isolated metaphorical expressions, but on their mutual relations in discourse and their evolution during the period in which data was collected.

In order to identify metaphorical expressions in the discourses of translation trainees, we adopted the criteria suggested by Cameron (2003: 59-61) and the method developed by the Pragglejaz research group (Steen et al. 2010), with some modifications:

- The first step was to identify expressions that could yield semantic or pragmatic inconsistencies between a "focus" or "vehicle" and the "topic", that is, the surrounding discourse (Black 1962, Cameron 2003). To this end, contextual meanings of these expressions were compared to their basic, decontextualized meanings as presented in a dictionary.

- The second step was to study whether the potential incongruity could be solved through mapping between two experiential domains.

The Pragglejaz group took the word as the unit of analysis (Steen et al. 2010: 26-27), but we also considered wider units of analysis when they could be related consistently to the same source conceptual domain. Metaphorical expressions can extend beyond the word to a phrase, a clause, a sentence or even a paragraph, and often it is difficult to determine their limits.

Metaphorical expressions were analyzed taking into account the context in which they were used, and they were categorized according to the experiential domains connected by them. In our work, we have adopted a view of metaphors as radial, open categories, defined by "family resemblances" between their members, and not by lists of necessary and sufficient conditions for category membership (Wittgenstein 1953; Lakoff 1987; Cameron 2003). This means that the identified metaphorical expressions may be mentally processed as metaphors to various degrees.

Consequently, we cannot be sure that all identified metaphors worked as cognitive metaphors. Nevertheless, we assumed that the use of more than one 
different linguistic metaphor connecting the same experiential domains consistently would increase the probability that they actually worked as cognitive metaphors. For this reason, we set to study the systematicity and coherence of metaphorical expressions in discourse. Context analysis allowed us to determine the degree of systematicity in their use. The results of this analysis are presented in section 5 .

\subsection{Translation process analysis}

Our analysis of process data is based on translation process research and on the analysis of pauses and text-production processes in discourse studies. Following text-production theories by Flower \& Hayes (1981) and Levelt (1989), we assume that producing a translation involves five types of cognitive processes: planning the text, retrieving information, formulating information, monitoring the results of previous processes, and repairing the text-produced-so-far. Translation process research approaches these processes with very diverse aims and methods. One of the recurrent findings is that these processes are distributed in three-phase patterns: orientation, drafting, and revision. The temporal organization of these phases allows for identifying different "translators' styles" (Carl, Dragsted \& Jakobsen 2011). We agree that orientation is related to planning, and assume that both the planning phase and the revision phase may be devoted to the holistic elaboration of the texts, and thus point to a macro strategic approach; in contrast, the absence of planning and/or revision would be indicative of a micro strategic approach.

Research has also focused on formulation and repairing processes, which in the past were observed in TAPs, and today mainly through recording keyboard activity. This interest is often associated to the notion of translation units (TU), which are conceived of in different ways (review in Alves \& Couto Vale 2009). In our research, we were also interested in the structure of text-production segments and text-correction patterns as indicators of the translator's approach. We assume that longer and more complex production and correction segments are indicators of a macrostrategic approach and, vice versa, shorter and simpler production and correction segments can be related to a microstrategic approach. Corrections can focus on the content or on the form of the text. Thus we distinguish between "semantic" and "ortotypographic" corrections, and relate the former with a macrostrategic approach and the latter with a microstrategic approach.

In this context, studying pauses is also relevant. As shown in previous research (review in Schilperoord 2002), it can be assumed that there is a relationship between pauses and at least three processes: retrieving, monitoring 
and repairing. Pauses, however, need to be considered as a "multi-determined phenomenon" (Schilperoord 2002: 75), that is, they may have multiple triggers. In our analysis, pauses had an essentially functional value and they are understood as markers of informants' text-production segments, although we identified initial pauses mainly with planning processes.

In sum, to characterize an individual's approach as micro-strategic or as macro-strategic, we analyzed three patterns of the translation process: (1) temporal distribution of the process; (2) structure of text-production segments; and (3) aim and scope of corrections. In this way, we sought to relate differences between theoretical models to those in the translation process.

\section{Results}

\subsection{Theories of translation trainees}

Traditionally, metaphor has been ubiquitous in discourses about translation, suggesting "that there was something about the process of translation which was best understood indirectly or by analogy" (St. André 2010:2). This was also the case in modern translation studies, which frequently used metaphors to describe and explain translation processes (Martín de León 2008, 2010). It also seems to be true in our informants' discourses, where we identified 1,046 metaphorical expressions, which we ascribed to 37 conceptual metaphors. Table 1 lists and describes these metaphors with the formula "THE TARGET DOMAIN IS THE SOURCE DOMAIN." More than half of the metaphorical expressions $(60 \%)$ construct the translation domain by means of another, more concrete or better structured domain: transferring objects, changing objects, moving to a target, putting oneself in somebody else's shoes, mechanical process, a growing tree, a chemical experiment, a picture and construction. The two most frequent metaphors were TRANSFER (323 tokens, 30.8\%) and CHANGE (161 tokens, 15.3\%). Furthermore, all informants used these metaphors.

Most of these metaphors are common in Spanish, the informants' first language. Informants only created $3(4.3 \%)$ of all identified conceptual metaphors: TRANSLATION IS A GROWING TREE, TRANSLATING IS PERFORMING A CHEMICAL EXPERIMENT and TRANSLATION IS A PICTURE. Some metaphors were adopted from the scientific theories discussed with the students (EQUIVALENCE, DETHRONEMENT, MAZE, TARGET). In some cases, an original metaphorical expression was ascribed to a generalized conceptual metaphor; for instance, 'a translator is a plug' was considered an expression of the conceptual metaphor TRANSLATING IS CONNECTING PEOPLE. In the following section, we present the theories that can be inferred from the two most frequent metaphors. 


\begin{tabular}{|c|c|c|}
\hline METAPHOR & Description & Tokens \\
\hline TRANSFER & Translating is transferring objects & 323 \\
\hline CHANGE & Translating is changing objects & 161 \\
\hline EQUIVALENCE & Similarity is equivalence & 127 \\
\hline SIGHT & Knowing is seeing & 80 \\
\hline TARGET & Translating is moving to a target & 34 \\
\hline EMPATHY & $\begin{array}{l}\text { Translating is putting oneself in somebody else's } \\
\text { place }\end{array}$ & 32 \\
\hline CREATION & Translating is creating a new text & 30 \\
\hline CONTAINER & The mind is a container & 28 \\
\hline MECHANICAL PROCESS & Translating is a mechanical process & 27 \\
\hline GROWTH & Translation is a growing tree & 24 \\
\hline MENTAL IMAGE & Translation is a mental image & 20 \\
\hline EXPERIMENT & Translating is making a chemical experiment & 18 \\
\hline REPRODUCTION & Translating is reproducing & 18 \\
\hline CONTACT & Translating is contacting the addressee & 15 \\
\hline MACHINE & The translator is a machine & 15 \\
\hline CONNECTION & Translating is connecting people & 13 \\
\hline PATH & The translation process is a path & 13 \\
\hline IMITATION & Translating is imitating & 12 \\
\hline DEPTH & Thorough is deep & 10 \\
\hline LINK & Similarity is a link between ST and TT & 6 \\
\hline PICTURE & Translation is a picture & 6 \\
\hline PROXIMITY & Similarity is proximity & 5 \\
\hline MANIPULATION & Translating is manipulating & 4 \\
\hline BARRIER & Differences are barriers & 4 \\
\hline CONSTRUCTION & Translating is constructing & 3 \\
\hline CONTROL & Quality is control & 3 \\
\hline ASSIMILATION & Translating is assimilating & 2 \\
\hline FLUIDITY & Text quality is fluidity & 2 \\
\hline DETHRONEMENT & Not imitating the ST is dethroning it & 2 \\
\hline SUBSTANCE & A culture is a substance & 2 \\
\hline INTERFERENCE & Confusion between languages is interference & 1 \\
\hline BLEND & Translating is blending & 1 \\
\hline
\end{tabular}




\begin{tabular}{|l|l|c|}
\hline INTERACTION & Translating is interacting & 1 \\
\hline RICHNESS & Knowledge is richness & 1 \\
\hline DYNAMICS & $\begin{array}{l}\text { Translating without imitating is translating } \\
\text { dynamically }\end{array}$ & 1 \\
\hline BLOCKADE & $\begin{array}{l}\text { Looking for a solution without success is being } \\
\text { blockaded }\end{array}$ & 1 \\
\hline MAZE & $\begin{array}{l}\text { Looking for a solution without success is wandering } \\
\text { through a maze }\end{array}$ & 1 \\
\hline
\end{tabular}

Table 1. Conceptual metaphors in informants' implicit theories.

\subsubsection{Translating is transferring objects}

The transfer metaphor has been identified and discussed in several scientific discourses about translation (Chesterman 1997; Martín de León 2008, 2010; Tymoczko 2010a). This metaphor provides a simplified view of translation as transfer of meanings between texts, languages or cultures, which are conceived of as containers. Just like the conduit metaphor (Reddy 1979/1993)—from which it can be considered an extension (Martín de León 2008, 2010)-the transfer metaphor portrays communication as sending information through language, and overlooks the active participation of interlocutors and translators in the process of constructing meaning. The main assumptions implicit in this metaphor are:

- Form (language) and content (meaning) are separable entities.

- Meaning is independent from the pragmatic, social and cultural context.

- Meaning is stable and independent from the communication partners.

- Meaning is an object that can be transferred between texts and between minds without undergoing any change.

- The translator's aim is to transfer meaning.

- The translator's task consists in extracting the meanings from the source text and transferring them to the target text, if possible without changes.

- There is at least partial identity between ST and TT.

The translation patterns that can be assumed to follow from this theory are:

- A demotion of the pragmatic, social and cultural factors of the communicative situation (Martín de León 2010:89) and, hence, a search for semantic equivalents. 
- A micro-strategic approach to translation (a focus on the translation of isolated units).

5.1.2. Translating is changing objects - The synthetic model TRANSFER/CHANGE The CHANGE metaphor depicts the translation process as a partial transformation of the source text. Translators carry out the changes they deem necessary to make the text more suitable for the needs of the addressees. This metaphor was generally used in combination with the TRANSFER metaphor, and prompted a synthetic model whereby, in order to convey source-text contents to the target text, it may be necessary to modify them. The main assumptions implicit in this model are:

- Form and content are separable entities.

- Meaning depends on the pragmatic, social and cultural context.

- Meaning depends on the communication partners.

- The translator's aim is to transfer meaning.

- In order to transmit the same meaning, it may be necessary to change its form.

- The translator's task consists of extracting meanings from the source text and transferring them to the target text, if necessary with changes.

- There is at least partial identity between ST and TT.

The translation patterns that can be deduced from this model are:

- Awareness of the potential addressees' interpretations and of pragmatic, social and cultural factors and, hence, search for pragmatic equivalents.

- A micro-strategic approach to translation.

\subsection{The evolution of theories through the evolution of metaphors}

The most frequent metaphor in the questionnaires filled out at the beginning of the semester was the TRANSFER metaphor. Hence, this metaphor might play an important role at structuring the translation trainees' initial implicit theories. In the interviews, when the researcher explicitly asked the students about their beliefs relating the TRANSFER metaphor, a consistent use of different vehicles related to this metaphor was detected (Martín de León \& Presas, forthcoming). The coherence of its use lets us hypothesize that it constitutes the main framework theory the trainees used as a point of departure in their learning process. 


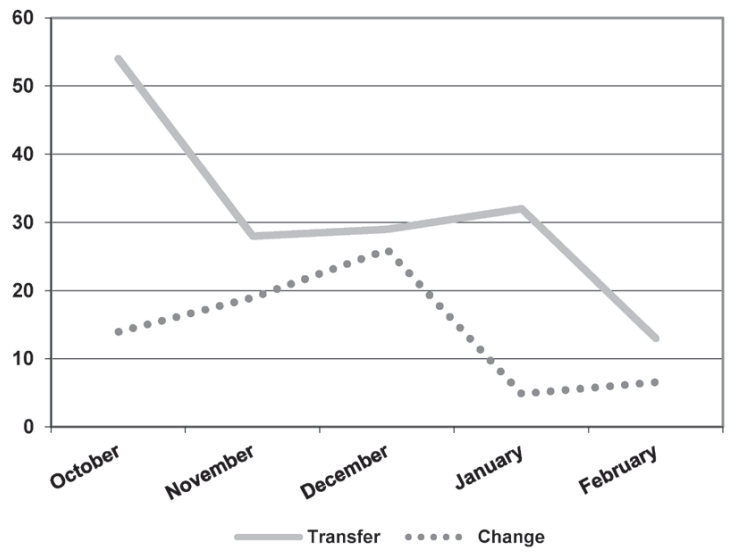

Figure 1. Evolution of the TRANSFER and the CHANGE metaphors.

The use of the transfer metaphor in students' statements (in questionnaires, interviews, essays and commentaries) decreased along the semester, and the use of the change metaphor increased significantly in the second half of the semester (November through December, see Figure 1). The increase in the use of the change metaphor happened in the period when the students were translating advertising texts, so to a certain extent their implicit theories might have been influenced by these translation exercises. In most cases, the students extended their initial theory based merely on the transfer of meaning to the target text with the inclusion of change, thereby adapting their theories to the requirements of the translation assignments. The change metaphor did not result in the development of a new model, but rather was adapted to the transfer metaphor, yielding a synthetic model where some of the transferred elements changed and the others remained identical (Martín de León \& Presas 2011).

The number of conceptual metaphors used by the students increased throughout the semester (17 in October; 33 in February). This increase was not linear, but it suggests a diversification of the source domains employed to talk and think about translation. The models used to explain the translation process became increasingly complex as well. In most cases, new elements (feelings, cultural factors) were added to the transfer model, or different metaphors (e.g., change, equivalence, and mechanical process) were combined to increase the scope. That is, a synthetic model was generated through additive mechanisms. Only very few cases seemed to indicate a true restructuring of the initial metaphor (growth, experiment, and creation). However, all 
students went on using metaphorical expressions of the transfer metaphor, even when they were inconsistent with their new models.

\subsection{Temporal distribution of the process}

The mean duration of all translation processes recorded with Translog was 2,768 seconds, although there were variations between informants (s.d., 373 seconds). Informants $(\mathrm{N}=10)$ devoted relatively little time to initial orientation, an average of 103 seconds (s.d., 89 seconds) and even less to revision-an average of 92 seconds (s.d., 178 seconds). This last finding is not very significant, since 6 informants devoted no time to revising while 1 informant devoted 787 seconds to this task. A comparison between informants shows that 4 of them spent more time than the average on their translations, while 4 of them spent less time than the average.

\subsection{Structure of text-production segments}

The mean length of the text-production segments is 1.8 words, with individual values ranging from 0.9 to 2.5 words. In this case it is worth noting that the median is 1 word. The most frequent type of segment is the word, with frequencies ranging from $49 \%$ to $59 \%$. At the other extreme, the sentence is the segment with the lowest frequency (between 1.6\% and 9.7\%).

As an example, we can take a closer look at text 2 (source text of 540 words), which occupies the mid-point in the data-collection process. All but 2 informants participated in this task. From the 8 participating informants, only 3 completed the translation. A comparison between the group of informants who could finish the task with the group of those who could not yields an average of 2.07 words for those who completed the translation, and 1.46 words in the second group. The three informants who completed their translation might have benefited from their slightly more "macro" approach to translation, which seems to enhance target formulation process.

\subsection{Aim and scope of corrections}

From a total of 3,634 registered corrections, $74.10 \%$ correspond to the category "ortho-typographic" and $25.90 \%$ to the "semantic" category-a reverse of this distribution (i.e., semantic corrections higher than ortho-typographic) was not found in any of the informants. The highest figure recorded for ortho-typographic corrections was $87.91 \%$ and the lowest, $53.18 \%$. In terms of the frequency of corrections by informants, $70.40 \%$ were made to the same word the informant was working on; $8.10 \%$, to the same clause; and only 
$7.10 \%$ went beyond the sentence boundaries. The predominance of corrections at the same word level applied to all informants, although there are considerable variations between them; for instance, one informant made $33.93 \%$ of all corrections at word level, while another one made $23.53 \%$ of all corrections beyond sentence boundaries.

\section{Discussion and further research}

The analysis of the informants' texts and interviews shows that metaphors were used not only to explain translation but also other related phenomena, although most instances revolved around translation. This predominance is very likely due to the setting and to the very aim of the questionnaires, but the use of conceptual metaphors may also point to the difficulty of conceptualizing translation processes. As we saw above, implicit theories mostly concentrate on the concepts of transfer and change, which are mutually consistent concepts, and were often combined. There is also a clear predominance of the TRANSFER metaphor as a structuring element when combined with other metaphors (e.g., CONTACT, EQUIVALENCE, CONTAINER or PAINTING). When knowledge implicit in these metaphorical models is compared to contemporary translation theories, it becomes apparent that such models are naive and do not reflect the complexity of translation phenomena. Initial metaphors were combined as new experiences and knowledge were acquired. Thus, formal instruction may prompt the restructuring of initial theories. The use of the TRANSFER and the CHANGE metaphors to conceptualize translation is pervasive in Western cultures, so the prevalence of these metaphors in the informants' initial theories lends support to the hypothesis that such theories are acquired as part of the enculturation process.

The results concerning the temporal distribution of the translation process show a high degree of dispersion, so they should be interpreted with due caution. Since time was limited, the mean process duration cannot be considered an indicator of the informants' way of working, although the fact that they concentrated their efforts in the editing phase may be deemed a specific trait. We did not find a clear distribution of operations for planning, information retrieval, and formulation. Data suggests that informants simultaneously perform monitoring and repairing tasks. We were also unable to find an individual "style" (cf. Carl, Dragsted, Jakobsen 2011)—some informants seem to follow a more homogeneous pattern throughout their translation tasks, whereas others show more disperse (or more flexible?) patterns.

The analysis of corrections suggests that informants concentrate their monitoring operations on structurally simple units (the word they are 
writing) and on formal (ortho-typography), rather than structural aspects. The predominance of ortho-typographic corrections may be attributed to a lack of typing skills or to spelling problems, and we cannot exclude insecurity or mental overload related to the translation task itself. Qualitative analysis of the writing process may help us discard the two first possible hypothetical causes. The high proportion of corrections devoted to repairing ortho-typographic errors helps to explain that most corrections have a very little scope -the same word-, and it also indicates that informants approach translating mainly at a micro level. The analysis of length and structure of text-production segments seems to confirm that indeed all the informants approached the translation process at a micro level both structurally and operationally: the word is their meaning unit and they process "one word after the other".

The data collection period was too short for us to detect an evolution in the process patterns. Unlike the data on implicit theories, process data does not show variations in their approach. This might be due to the fact that the evolution in theories, as reflected in the transition from TRANSFER to CHANGE metaphors, does not lead to a real change in approach and/or to the construction of a new more complex theory that could lead to changes in the process. In addition, we assume that the process as such is essentially unconscious and thus more difficult to change. From a methodological point of view, this conclusion poses the need not only to develop data-collection instruments and analysis procedures sensitive to changes in the process, but also to design a longitudinal study.

From the results of the production process, we cannot conclude that the comprehension unit during the reading process is also the word, but that possibility cannot be excluded either. We intend to collect data on the reading process to study whether they also read "one word after the other".

Finally, the analysis of the translations will provide some insights into the informants' decision patterns concerning their priorities (formal imitation of source text vs. orientation to the addressee). Results from this analysis should help us to find out further correlations between implicit theories and the translation practice.

\section{References}

Alves, Fábio \& Daniel Couto Vale. (2009) "Probing the unit of translation in time: Aspects of the design and development of a web application for storing, annotating, and querying translation process data." Across Languages and Cultures 10:3, pp. 251-273.

BlaCK, Max. (1962) Models and Metaphors. New York: Cornell University Press. 
CAMERon, Lynne. (2003) Metaphor in Educational Discourse. London: Continuum. CAmeron, Lynne. (2007) "Patterns of metaphor use in reconciliation talk." Discourse \& Society 18:2, pp. 197-222.

CAMERON, Lynne \& Alice Deignam. (2006) "The emergence of metaphor in discourse." Applied Linguistics 27:4, pp. 671-690.

Cameron, Lynne \& Juurd H. Stelma. (2004) "Metaphor clusters in discourse." Journal of Applied Linguistics 1:2, pp. 107-136.

CARL, Michael; Barbara Dragsted \& Arnt L. Jakobsen. (2011) "A taxonomy of human translation styles." Translation Journal 10:2. Electronic version available at: <http://www.bokorlang.com/journal/56taxonomy.htm>.

Chesterman, Andrew. (1997) Memes of Translation. Amsterdam: John Benjamins.

DANN, Hanns-Dietrich. (1990) "Subjective theories: A new approach to psychological research and educational practice." In: Semin, Gün R. \& Kenneth J. Gergen (eds.) 1990 Everyday Understanding. Social and Scientific Implications. London: SAGE, pp. 227-243.

D’HULST, Lieven. (1992) "Sur le rôle des métaphores en traductologie contemporaine." Target 4:1, pp. 33-51.

FLICK, Uwe. (2007) Designing Qualitative Research. Los Angeles: SAGE.

FLOWER, Linda \& John R. Hayes. (1981) "A cognitive process theory of writing." College Composition and Communication 32:4, pp. 365-387.

Groeben, Norbert. (1988) "Explikation des Konstrukts 'Subjektive Theorie'." In: Groeben, Norbert; Diethelm Wahl; Jörg Schlee \& Brigitte Scheele (eds.) 1988 Das Forschungsprogramm subjektive Theorien. Eine Einführung in die Psychologie des reflexiven Subjekts. Tübingen: Francke, pp. 12-24.

HANSEN, Gyde. (2004) "Die Beschreibung von Übersetzungsprozessen." In: Fleischmann, Eberhard; Peter. A. Schmitt \& G. Wotjak (eds.) 2004 Translationskompetenz. Tübingen: Stauffenburg, pp. 91-101.

HÖNIG, Hans. (1997) Konstruktives Übersetzen. Tübingen: Stauffenburg.

JÄASKELÄINEN, Riita. (2002) "Think-aloud protocol studies into translation. An annotated bibliography." Target 14:1, pp. 107-136.

KöveCSES, Zoltán. (1986) Metaphors of Anger, Pride and Love. A Lexical Approach to the Structure of Concepts. Amsterdam: John Benjamins.

KÖVECSES, Zoltán. (2005) Metaphor in Culture. Universality and Variation. Cambridge: Cambridge University Press.

KÖVECSES, Zoltán. (2009) "The effect of context on the use of metaphors in discourse." Iberica 17, pp. 11-24.

KRINGS, Hans P. (1986) Was in den Köpfen von Übersetzern vorgeht. Eine empirische Untersuchung zur Struktur des Übersetzungsprozesses an fortgeschrittenen Französischlernern. Tübingen: Günter Narr.

KRINGS, Hans P. (2005) "Wege ins Labyrinth - Fragestellungen und Methoden der Übersetzungsprozessforschung im Überblick. “ Meta 50:2, pp. 342-358. 
LAKOFF, George. (1987) Women, Fire and Dangerous Things. What Categories Reveal about the Mind. Chicago: University of Chicago Press.

LAKOFF, George. (1993) "The contemporary theory of metaphor." In: Ortony, Andrew (ed.) 1993 Metaphor and Thought. 2nd edition. Cambridge: Cambridge University Press, pp. 202-251.

LAKOFF, George \& Mark Johnson. (1980) Metaphors We Live By. Chicago: The University of Chicago Press.

LAKOFF, George \& Zoltán Kövecses. (1987) "The cognitive model of anger inherent in American English.” In: Holland, Dorothy \& Naomi Quinn (eds.) 1987 Cultural Models in Language $\&$ Thought. Cambridge: Cambridge University Press, pp. 195-226.

LEVELT, Willem J. M. (1989) Speaking: From Intention to Articulation. Cambridge, MA: The MIT Press.

LÖRSCHER, Wolfgang. (2005) "The translation process: Methods and problems of its investigation." Meta 50:2, pp. 597-608.

MANDL, Heinz. (1998) "Implementationsforschung - Einführung in das Thema." Unterrrichtswissenschaft. Zeitschrift für Lernforschung 26:4, pp. 290.

MARTín DE LEÓn, Celia. (2008) "Skopos and beyond. A critical study of functionalism." Target 20:1, pp. 1-28.

MARTín DE LEÓN, Celia. (2010) "Metaphorical models of translation. Transfer vs. imitation and action. In: St. André, James (ed.) 2010 Thinking Through Translation with Metaphors. Manchester: St. Jerome, pp. 75-108.

MARTín de León, Celia \& Marisa Presas. (2011) "Metaphern als Ausdruck subjektiver Theorien zum Übersetzen. Eine empirische Untersuchung zur konzeptuell-strukturierender Funktion von Metaphernmodellen bei Studienanfängern." Target 23:2, pp. 272-310.

MARTín DE LEÓn, Celia \& Marisa Presas. [Forthcoming] "Novice translators' discourse: An empirical study of subjective theories of translation reflected in metaphors. In: Mussolf, Andreas \& Fiona Macarthur (eds.) 2013. Metaphor and Metonymy in Intercultural Communication. London: Bloomsbury.

Muñoz MARTín, Ricardo. (2008) Apuntes para una traductología cognitiva. In: Pegenaute, Luis; Janet DeCesaris; Mercè Tricás \& Elisenda Bernal (eds.) 2008 Actas del III Congreso Internacional de la AIETI. La traducción del futuro: mediación lingüística y cultural en el siglo XXI. Barcelona 22 -24 de 2007. Barcelona: PPU, pp. 65-75.

MuÑoz MARTín, Ricardo. (2010) "Leave no stone unturned." Translation and Interpreting Studies 5:2, pp. 145-162

MusolfF, Andreas. (2004) "Metaphor and conceptual evolution." metaphorik.de 7, pp. $55-75$.

MusolfF, Andreas \& Jörg Zinken. (2009) Metaphor and Discourse. Basingstoke: Palgrave Macmillan. 
NeUnZiG, Wilhelm. (2002) "Estudios empíricos en traducción: Apuntes metodológicos." Cuadernos de Tradução 10, pp. 75-96.

OrdóÑEz LÓPEZ, María del Pilar. (2010) "De mayor quiero ser traductor. Estudio de las preconcepciones de los alumnos de primer curso del Grado en Traducción e Interpretación." inTRAlinea 12. Electronic version available at: <http:// www.intralinea.it/volumes/eng_more.php?id=870_0_2_0>.

Orozco Jutorán, Mariana. (2002) "Revisión de investigaciones empíricas en traducción escrita." Trans 6, pp. 63-85.

PACTE. (2008) "First results of a translation competence experiment: 'Knowledge of Translation' and 'Efficacy of the Translation Process'." In: Kearns, John (ed.) 2008 Translator and Interpreter Training. Issues, Methods and Debates. London: Continuum, pp. 104-116.

Pozo, Juan Ignacio. (2003) Adquisición de conocimiento. Madrid: Morata.

PRESAS, Marisa \& Celia Martín de León. (2011) "Teorías implícitas de traductores principiantes. Una investigación cualitativa en traductología cognitiva." Sendebar 22, pp. 87-111.

REBER, Arthur S. (1993) Implicit learning and tacit knowledge. An essay on the cognitive unconscious. Oxford: Oxford University Press.

REDDY, Michael. ([1979] 1993). "The conduit metaphor: A case of frame conflict in our language about language." In: Ortony, Andrew (ed.) 1993 Metaphor and Thought. 2nd edition. Cambridge: Cambridge University Press, pp. 164-201.

Rodrigo, María José; Armando Rodríguez \& Javier Marrero. (1993) Las teorías implícitas. Una aproximación al conocimiento cotidiano. Madrid: Visor.

RODRIGUES, Cassio. (2001) Überzeugungen im Übersetzungsprozess: Eine empirische Untersuchung mit Berufsübersetzern. Unpublished doctoral dissertation. Ruhr-Universität Bochum, Fakultät für Philogogie.

RODRIGUES, Cassio. (2002) "A abordagem processual no estudio da tradução: uma meta-análise qualitativa." Cuadernos de Tradução 10:2, pp. 23-57.

Ross, Lee. (1997.) "The intuitive psychologist and his shortcomings: Distortions in the attribution process." In: Berkovitz, Leonard (ed.) 1997 Advances in Experimental Social Psychology. New York: Academic Press, pp. 174-220.

SHILPEROORD, Joost. (2002) "On the cognitive status of pauses in discourse production." In: Olive, Thierry \& C. Michael Levy (eds.) 2002 Contemporary Tools and Techniques for Studying Writing. Dordrecht: Kluwer, pp. 61-90.

ST. ANDRÉ, James. (2010) "Translation and metaphor. Setting the terms." In: St. André, James (ed.) 2010 Thinking Through Translation with Metaphors. Manchester: St. Jerome, pp. 1-16.

SteEn, Gerard J.; Aletta G. Dorst; J. Berenike Herrmann; Anna Kaal; Tina Krennmayr \& Trijntje Pasma. (2010) A Method for Linguistic Metaphor Identification. From MIP to MIPVU. Amsterdam: John Benjamins. 
TYMOCZKO, Maria. (2003) Enlarging western translation theory: Integrating non-western thought about translation. Electronic version available at: <http:// www.soas.ac.uk/literatures/satranslations/tymoczko.pdf>.

TYMOzCO, Maria. (2010a) "Western metaphorical discourses implicit in translation studies." In: St. André, James (ed.) 2010 Thinking Through Translation with Metaphors. Manchester: St. Jerome, pp. 109-143.

TyMozco, Maria. (2010b) Enlarging Translation, Empowering Translators. Manchester: St. Jerome.

VERMEER, Hans Jürgen (1992). Skizzen zu einer Geschichte der Translation. Frankfurt: Verlag für Interkulturelle Kommunikation.

Vygotsky, Lev. (1962) Thought and Language. Cambridge: MIT Press.

Vosniadou, Stella. (2008) "Conceptual change research: An introduction." In: Vosniadou, Stella (ed.) 2008 International Handbook of Research on Conceptual Change. London: Routledge, pp. xiii-xxviii.

VosniAdOU, Stella; Xenia Vamvakoussi \& Irini Skopeliti. (2008) "The framework theory approach to the problem of conceptual change." In: Vosniadou, Stella (ed.) 2008 International Handbook of Research on Conceptual Change. New York, London: Routledge, pp. 3-34.

WAHL, Diethelm. (1994) "Handlugnsvalidierung." In: Huber, Günter L. \& Heinz Mandl (eds.) 1994 Verbale Daten. Eine Einführung in die Grundlagen und Methoden der Erhebung und Auswertung. Weinheim: Beltz, pp. 259-274.

Wittgenstein, Ludwig. (1953) Philosophical Investigations. Oxford: Blackwell. 
Appendix I. Questions in the sociolinguistic questionnaire

\section{PERSONAL}

NOMBRE:

Fecha de nacimiento:

Lugar de nacimiento:

Lugar de residencia habitual:

¿Cuánto tiempo hace que resides en Las Palmas?

¿Has vivido en algún otro lugar?

¿En dónde?

¿Cuánto tiempo?

¿Has realizado estancias en el extranjero?

¿Dónde?

¿Cuánto tiempo?

¿Has estudiado alemán en algún otro país?

¿Dónde?

\section{ENTORNO INMEDIATO}

Nacionalidad del padre:

Nacionalidad de la madre:

Lengua materna o de uso habitual:

¿Algún familiar, amigo o persona del entorno cercano habla alemán muy bien? ¿Te comunicas habitualmente en alemán?

\section{LENGUAS}

Español

¿Lees habitualmente la prensa?

¿Cuántas veces al mes?

¿Lees habitualmente literatura en español?

¿Cuántos libros al año?

¿Lees otro tipo de libros? ¿De qué tema?

¿Escribes o has escrito (literatura)?

Si la respuesta anterior es sí, ¿qué género(s)?

Si lo has dejado, ¿por qué?

Alemán

¿Cuál es tu nivel de alemán en...

... comprensión oral? (1- mínimo/8-nativo)

... expresión oral? (1-mínimo/8-nativo)

... comprensión escrita? (1-mínimo/8-nativo) 
... expresión escrita? (1-mínimo/8-nativo)

¿Cómo aprendiste alemán?

Enseñanza reglada (primaria, secundaria; indicar el centro)

Escuela Oficial de Idiomas (indicar el número de cursos)

Clases particulares

Cursos con estancia en otros países (indicar lugar y número de meses)

Otros

¿Lees prensa en alemán habitualmente?

¿Cuántas veces al mes?

¿Lees habitualmente literatura en alemán?

¿Cuántos libros al año?

¿Lees otro tipo de libros? ¿De qué tema?

¿Ves televisión en alemán?

¿Cuántas horas por semana?

¿Escuchas la radio en alemán?

¿Cuántas horas por semana?

Otras lenguas

¿Hablas alguna otra lengua extranjera?

Lengua ...

Comprensión oral (1-mínimo/8-nativo)

Expresión oral? (1-mínimo/8-nativo)

Comprensión escrita? (1-mínimo/8-nativo)

Expresión escrita? (1-mínimo/8-nativo)

Lengua ...

Comprensión oral (1-mínimo/8-nativo)

Expresión oral? (1-mínimo/8-nativo)

Comprensión escrita? (1-mínimo/8-nativo)

Expresión escrita? (1-mínimo/8-nativo)

\section{AFICIONES}

¿Cuántas veces al mes vas...

... al cine?

... al teatro?

... a espectáculos musicales?

... a conferencias?

... a espectáculos deportivos?

¿Practicas algún deporte? ¿Cuál?

¿Tienes alguna afición o hobby? ¿Cuál? 
¿Cuántas horas a la semana ves la televisión?

¿Cuántas horas a la semana sales a bares y discotecas?

\section{ESTUDIOS}

¿Tienes un ordenador para tu uso exclusivo?

¿Has completado algún título universitario? ¿Cuál?

¿Has cursado parcialmente estudios de algún otro título universitario? ¿Cuál?

¿Has cursado algún otro tipo de estudios profesionales no universitarios?

¿Cuáles?

¿Fue Traducción e Interpretación tu primera elección?

Si tu primera elección no era traducción, ¿cuál fue?

¿Por qué escogiste traducción?

\section{PROFESIÓN}

¿Deseas ser traductor/a o intérprete?

Si la respuesta anterior es sí, ¿con qué perfil?

Si no pudieras trabajar como traductor/a o intérprete, ¿en qué te gustaría trabajar?

Si no deseas trabajar como traductor/a o intérprete, ¿en qué te gustaría trabajar?

¿Vas a seguir estudiando cuando te licencies?

Si la respuesta anterior es sí, ¿qué deseas estudiar?

¿Desearías completar tu formación como traductor/a o intérprete?

Si la respuesta anterior es sí, ¿qué deseas estudiar?

A la vista de la información recabada en la encuesta, ¿deseas añadir algo?

Appendix II. Questions in the questionnaire about translation

\section{NOMBRE}

¿Has traducido alguna vez?

Si la respuesta anterior es sí, ¿de qué lengua a qué lengua?

¿qué tipo de textos?

¿En qué contexto (como ejercicio de clase, por propia iniciativa, por encargo, profesionalmente, etc.)?

¿Qué es para ti traducir?

¿Qué tipo de textos prefieres traducir?

¿Qué crees que debe saber un traductor? 
¿Qué te gustaría aprender en la carrera?

¿Cuáles son los principales problemas con los que, en tu opinión, se encuentra un traductor?

¿Cómo describirías el proceso de traducción?

¿Cómo definirías la traducción...

... desde un punto de vista textual? ¿Qué es traducir un texto?

... desde un punto de vista social? ¿Qué personas intervienen en el proceso y qué hacen?

... desde un punto de vista cognitivo? ¿Qué ocurre en la mente del traductor?

A la vista de la información recabada en la encuesta, ¿deseas añadir algo?

Appendix III. Questionnaire about translation models

Nombre

1. Esboza un esquema del proceso de traducción tal y como tú te lo imaginas cuando estás traduciendo. No hace falta que sea un esquema detallado, sino más bien una imagen mental general del proceso.

2. Si tuvieras que usar una imagen o metáfora para explicar lo que pasa al traducir un texto, ¿cuál elegirías? Puedes describirla y/o dibujarla.

\section{BIONOTES / NOTAS BIOGRÁFICAS}

Marisa Presas is Professor at the Department of Translation and Interpreting of the Universitat Autònoma de Barcelona since 1977. She has carried out research in the fields of translation competence and its acquisition; evaluation and self-assessment methods in the training of translators; and the role of the translator in the translation of children's literature. Currently her main research interest is the analysis of the implicit theories of novice translators and their influence on the translation process. She is a member of the Tradumática Research Group, which deals with the application of ICTs to the translation process, and the Research Group "Expertise and Environment in Translation" (PETRA, Spanish acronym), that empirically studies the behavior of the translator from a cognitive perspective.

Marisa Presas es profesora del Departamento de Traducción e Interpretación de la UAB desde 1977. Ha investigado en ámbitos como la competencia 
traductora y su adquisición, los métodos de evaluación y autoevaluación en la formación de traductores, y el papel del traductor en la traducción de literatura infantil y juvenil. En la actualidad, su línea de investigación principal es el análisis de las teorías implícitas de traductores principiantes y de su influencia en el proceso de traducción. Es miembro del grupo Tradumática, que se ocupa de la aplicación de las TIC al proceso de traducción, y del grupo «Pericia y Entorno de la Traducción» (PETRA), que estudia empíricamente el comportamiento del traductor desde una perspectiva cognitiva.

Celia Martín de León has been a freelance translator since 1990. Martín obtained her European doctoral degree on Translating and Interpreting in 2003 at the University of Las Palmas de Gran Canaria (Spain). Her main research interests are the analysis of metaphors used in translatology; the study of translation processes from the viewpoint of embodied, embedded and distributed cognition; and the analysis of the implicit theories entertained by translation students and their influence on the practice. Since 2002 she has belonged to the Research Group "Expertise and Environment in Translation" (PETRA, Spanish acronym), devoted to empirical research into translation processes. She has been teaching translation since 1995 at the University of Las Palmas de Gran Canaria.

Celia Martín de León es traductora autónoma desde 1990. En 2003 se doctoró en Traducción e Interpretación en la ULPGC. Su trabajo de investigación se centra en el análisis de las metáforas usadas en el campo de la traductología, en el estudio de los procesos de traducción desde el punto de vista de la cognición corpórea, situada y distribuida; y en el análisis de las teorías implícitas de los estudiantes de traducción y su relación con la práctica. Desde 2002 forma parte del grupo de investigación «Pericia y Entorno de la Traducción» (PETRA), dedicado a la investigación empírica de los procesos de traducción desde una pespectiva cognitiva. Desde 1995 imparte docencia en la Facultad de Traducción e Interpretación de la ULPGC. 